\title{
Genetic Determinants of Osteoporosis: Common Bases to Cardiovascular Diseases?
}

\author{
Francesca Marini and Maria Luisa Brandi \\ Department of Internal Medicine, University of Florence, Viale Pieraccini, 6, 50139 Florence, Italy \\ Correspondence should be addressed to Maria Luisa Brandi, m.brandi@dmi.unifi.it
}

Received 30 December 2009; Accepted 7 February 2010

Academic Editor: Tomohiro Katsuya

Copyright (๑) 2010 F. Marini and M. L. Brandi. This is an open access article distributed under the Creative Commons Attribution License, which permits unrestricted use, distribution, and reproduction in any medium, provided the original work is properly cited.

\begin{abstract}
Osteoporosis is the most common and serious age-related skeletal disorder, characterized by a low bone mass and bone microarchitectural deterioration, with a consequent increase in bone fragility and susceptibility to spontaneous fractures, and it represents a major worldwide health care problem with important implications for health care costs, morbidity and mortality. Today is well accepted that osteoporosis is a multifactorial disorder caused by the interaction between environment and genes that singularly exert modest effects on bone mass and other aspects of bone strength and fracture risk. The individuation of genetic factors responsible for osteoporosis predisposition and development is fundamental for the disease prevention and for the setting of novel therapies, before fracture occurrence. In the last decades the interest of the Scientific Community has been concentrated in the understanding the genetic bases of this disease but with controversial and/or inconclusive results. This review tries to summarize data on the most representative osteoporosis candidate genes. Moreover, since recently osteoporosis and cardiovascular diseases have shown to share common physiopathological mechanisms, this review also provides information on the current understanding of osteoporosis and cardiovascular diseases common genetic bases.
\end{abstract}

\section{Introduction}

Osteoporosis is the most common age-related skeletal chronic disorder, characterized by reduced bone mass, deterioration of bone micro-architecture and increased risk of low-trauma fractures. Fragility fractures are the endpoint of osteoporosis and represent the major cause of morbidity and mortality. With the constant growing age of population, not only in developed countries but also in South America, Asia, and Africa, osteoporosis is becoming more and more a worldwide major public health problem. Today over two hundreds millions people worldwide and the thirty per cent of all postmenopausal women in USA and Europe are affected by osteoporosis. At least $40 \%$ of all affected women and $15-30 \%$ of all affected men will suffer a fragility fracture during their lifetime. The individuation of factors responsible for osteoporosis predisposition and development is fundamental for disease prevention and for setting of novel therapies.
According to the International Osteoporosis Foundation (IOF) guidelines, osteoporosis risk factors can be divided into two main classes: (1) modifiable risks that depend principally on lifestyle and nutrition habits and can be modified and (2) fixed risks that are innate and cannot be modified. Main osteoporosis risk factors are depicted in Table 1.

Today Scientific Community agrees that osteoporosis is a complex multifactorial disorder caused by the interaction between environmental factors and genes that singularly exert modest effects on bone metabolism and fracture risk. Studies on osteoporosis sibs and families demonstrated that genetic factors are responsible for about $60-85 \%$ of inter-individual variability of bone mineral density (BMD) $[1,2]$, and this effect appears to persist even in the late decades of life. BMD heritability varies between different skeletal sites [3]. Also fragility fracture risk seems to have a genetic component; family history of fracture has been shown in some epidemiological studies as a risk factor for 
TABLE 1: Main risk factors for osteoporosis.

\begin{tabular}{ll}
\hline $\begin{array}{l}\text { Osteoporosis modifiable } \\
\text { risks }\end{array}$ & Osteoporosis fixed risks \\
\hline (i) Alchool & (i) Age \\
(ii) Smoking & (ii) Ethnicity \\
(iii) Low body mass index & (iii) Female gender \\
(iv) Poor nutrition & (iv) Family history of fractures \\
(v) Eating disorders & (v) Previous fractures \\
(vi) Insufficient physical & (vi) Menopause/hysterectomy \\
activity & (vii) Hormonal status \\
(vii) Low dietary calcium & (viii) Long-term glucocorticoid \\
(viii) Vitamin D deficiency & therapy \\
(ix) Frequent falls & (ix) Primary/secondary \\
\end{tabular}

fractures $[4,5]$. Interestingly, the heritability of fractures has been shown to be independent of BMD and maybe influenced by other factors such as bone geometry, bone turnover or the risk of falling. However, the heritability of fractures seems to decrease with age maybe as environmental factors become more important. Other bone features such as quantitative ultrasound properties, femoral neck geometry, bone turnover markers range have been demonstrated to be under the control of genetic factors [6, 7]. Except for some rare Mendelian monogenic inherited osteoporosis forms (osteoporosis associated with estrogen deficiency due to inactivating mutation of the aromatase gene (CYP19) [8] or associated with estrogen resistance due to inactivating mutation of the estrogen receptor alpha $(E R \alpha)$ gene [9], and autosomal recessive osteoporosis pseudoglioma caused by inactivating mutation of lipoprotein receptor-related protein 5 (LRP5) [10], classic age-related osteoporosis is a multifactorial heterogeneous disorder and, to date, its exact genetic bases are still unknown. In fact, bone metabolism is regulated by several genes, some exerting a high degree of influence (major genes) and other, even more numerous, exerting minor effects (minor genes). Due to the complex biology of the skeleton, putative osteoporosis candidate genes are very numerous and the number of genes identified to be involved in bone metabolism is constantly increasing. They include genes involved in the regulation of bone and calcium metabolism, such as those encoding for calciotrophic and sex hormones and their receptors, for bone matrix proteins, for cytokines, growth factors and local mediators and their receptors, and for proteins involved in molecular pathways of bone cells. Principal osteoporosis candidate genes are described in Table 2.

Moreover, the presence of epigenetic regulative factors, gene-gene and gene-environment interactions complicate the situation. Different genetic and environmental factors may result in the same osteoporotic phenotype and it is also possible that some individuals having one or more predisposing alleles and genetically at risk of osteoporosis never become osteoporotic or, controversially, individuals with no predisposing alleles may develop osteoporosis with age due to non-genetic factors.

Candidate gene association studies have identified several polymorphisms associated to BMD, bone characteristics and fragility fracture risk. However, these association studies generated conflicting results may be due to inadequate population sampling, ethnicity, gender, age, confounding factors, lack of standardized genotyping methods, gene-gene interactions, linkage disequilibrium with other trait-causing polymorphisms in a nearby locus, epigenetic and/or posttranscriptional gene expression regulation (i.e., microRNAs) and gene-environment interactions. Retrospective metaanalyses, including several different association studies, and multicentric studies on large and well characterized populations are both helpful in reducing these issues and increasing the power of statistical associations. Several reviews on genetics of osteoporosis tried to summarize the most representative osteoporosis association studies [11-15].

Some of the most important and most studied osteoporosis candidate genes will be briefly discussed below, with specific focus on the results of the European Genomos study. The Genomos (Genetic Markers for Osteoporosis) study is an European multicentric consortium that collected over 20000 Caucasian subjects (women and men) from several European centers, using prospective genotyping with cross-center standardization, for the study of osteoporosis candidate genes.

For years osteoporosis and cardiovascular diseases (CVDs) have been considered as two independent consequences of aging, however, recent evidences support an association between these two diseases, indicating common physiopathological mechanisms, and maybe genetic bases.

\section{Osteoporosis and Cardiovascular Diseases}

Some studies have reported associations between age-related CVDs and bone loss and have indicated common etiologies for CVDs and osteoporotic fractures with a substantially increased risk of hip fractures in women after the diagnosis of a CVD [16-19].

More than $90 \%$ of atherosclerosis fatty plaques undergo calcification. Now it is well assessed that calcium metabolism has a central role both in bone mineralization and on the risk of arteriosclerosis development and progression, since regulatory factors of bone cells functions can also affect vascular calcification. Osteoprotegerin (OPG) and receptor activator of nuclear factor kappa B ligand (RANKL) regulate osteoclast activation and function but are also involved in the vascular calcification process and atherosclerosis [20, 21]. Bone morphogenetic protein (BMP2) is involved in osteoblastic differentiation by the stimulation of Runx 2 expression; in humans, atherosclerotic lesions show an increased expression of BMP2 and Runx2 with respect to normal arteries [22] and this may be responsible for arteries wall calcification. Some others biological and environmental factors seem to be involved both in altered bone mineralization and in vascular calcifications, such as vitamin D insufficiency, low calcium intake, estrogen deficiency, chronic inflammation, oxidative 


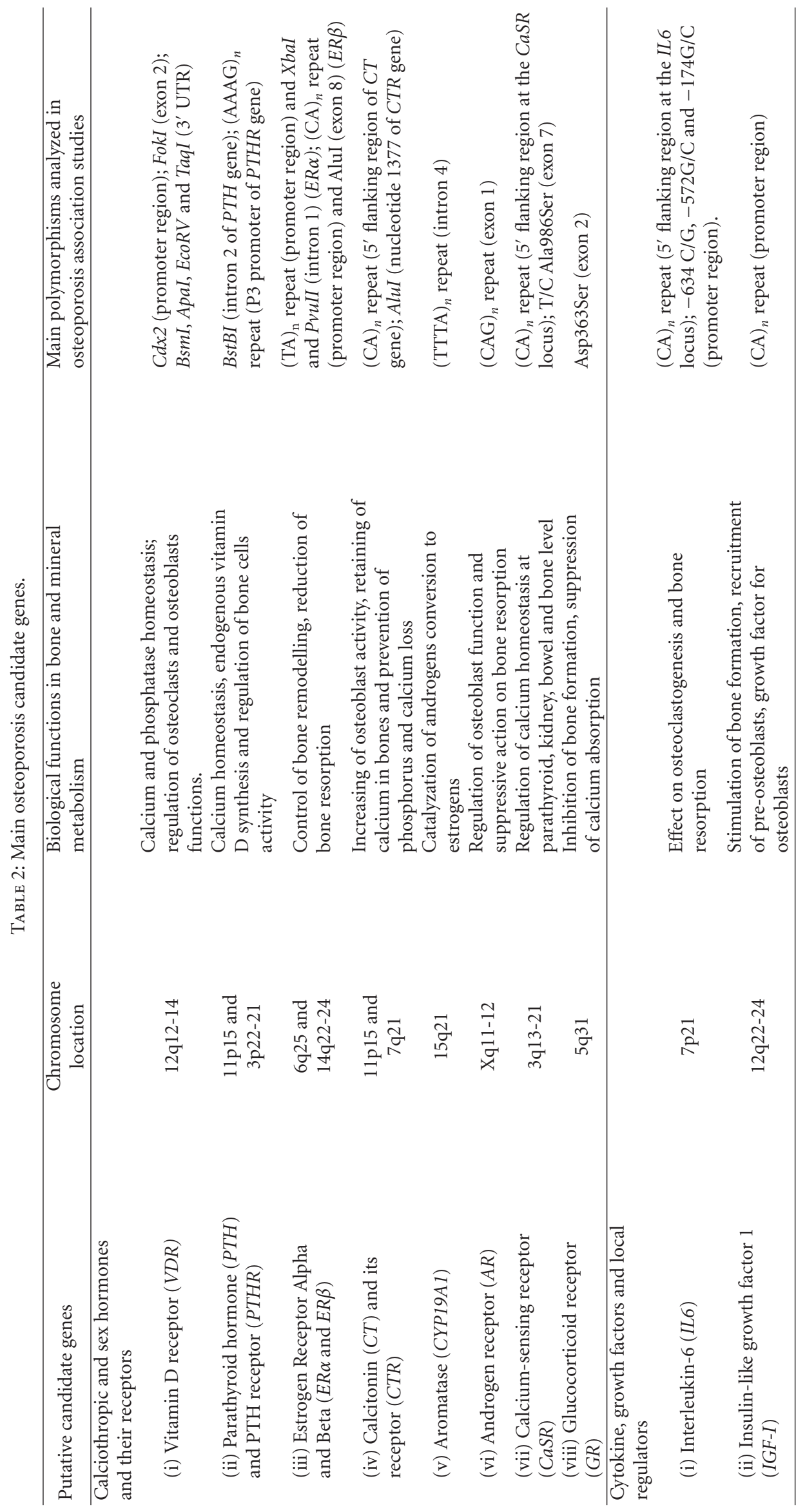




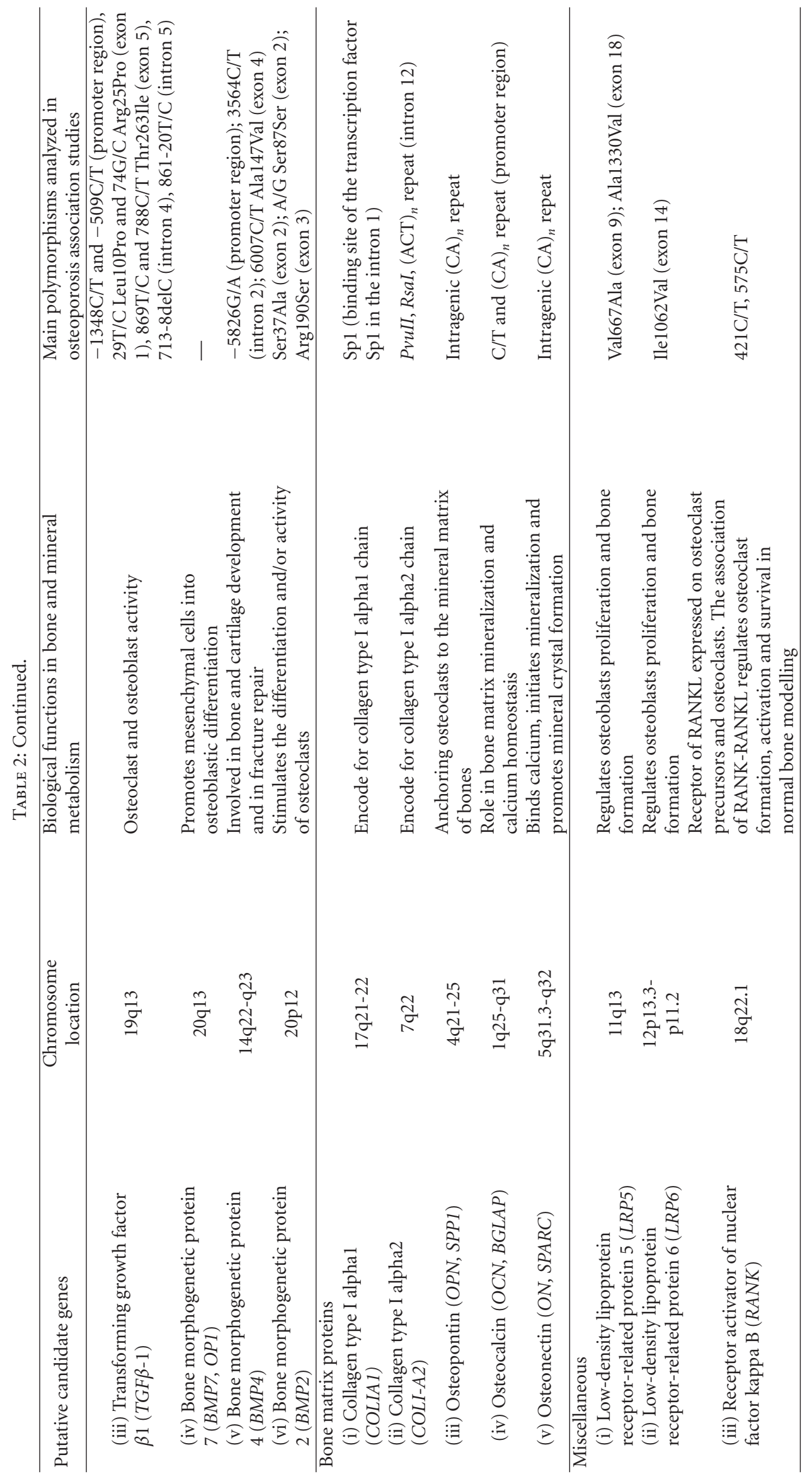




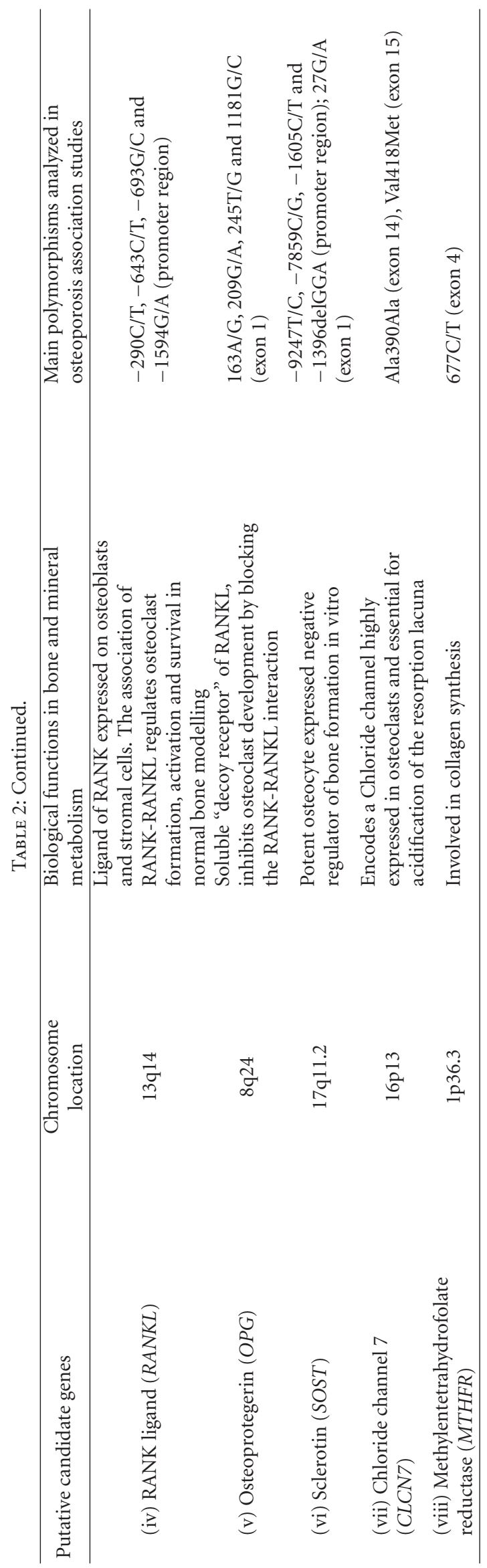


stress, dyslipidemia, high dietary fat intake, smoking, low physical activity. Elderly people present with calcium and vitamin $\mathrm{D}$ deficiency that could contribute to calcium mobilization from bones with consequently higher risk of fractures and of severe vessels and arteries calcification. At the same time the age-related estrogen deficiency may induce the increase of pro-inflammatory cytokines (IL1, IL6 and $\mathrm{TNF} \alpha$ ) that enhances the expression of adhesion molecules on leukocytes and endothelial cells favoring the progression of atherosclerosis plaques. Estrogen deficiency also induces the decrease of OPG with subsequent calcium mobilization from bones and risk of calcification of atherosclerosis plaques. Last, estrogen deficiency induces a reduction of production of nitric oxide which has athero-protective effects but also plays a role in osteoblast function and regulates the endothelial function of bone microcirculation. Moreover, elevated LDL and low HDL cholesterol, suspected to be responsible for atherosclerosis, are associated also with low BMD and with vertebral fractures in postmenopausal women [23]. The altered lipid metabolism is associated with both bone remodeling and atherosclerosis process [22] and this may explain, in part, the coexistence of atherosclerosis and osteoporosis in patients with dyslipidemia.

Animal, clinical and epidemiological studies suggest that high blood pressure is associated with abnormalities of calcium metabolism, leading to increased calcium loss, increased movement of calcium from bone and long-term risk of bone demineralization and osteoporosis [24-26]. Metabolic studies in hypertensive rats showed that associated hypercalciuria and secondary activation of parathyroid glands induced a reduced growth and a decreased bone mineral content later in life $[27,28]$. The mechanisms by which this occurs are probably due to a defect in the kidney ability to handle calcium. Moreover, cross-sectional studies $[29,30]$ in humans have shown an inverse positive association between blood pressure and bone mineral density, supporting a possible correlation between hypertension and osteoporosis.

Last, recent evidences of the action of bone antiresorptive drugs also on the reduction of CVDs risk and evidences of the positive effect of statins, antihypertensive drugs and insulin on bone mass increase [22, 31-33] suggest that osteoporosis and CVDs share common physiopathological molecular pathways. Bisphosphonates are potent antiresorptive agents widely used in osteoporosis treatment and in prevention of fracture risk. Experimental studies on animal models demonstrated that bisphosphonates also inhibit arterial and cardiac calcification in mice [34] and prevent foam cell formation by inhibiting LDL uptake and macrophages replication [33]. Raloxifene is a selective estrogen receptor modulator prescribed for both the prevention and treatment of osteoporosis and with a proven efficacy in the reduction of risk of fragility fractures. Raloxifene seems to have favorable effects on LDL cholesterol level and risk of coronary heart disease and it improves vascular endothelial function in postmenopausal women $[35,36]$. The results from the MORE (Multiple Outcomes of Raloxifene Evaluation) randomized trial made possible to decipher the effects of raloxifene on cardiovascular events in osteoporotic postmenopausal women, evidencing that raloxifene therapy for 4 years did not significantly affect the risk of cardiovascular events in the overall studied population but it significantly reduced this risk in the subpopulation of women with increased cardiovascular risk [37]. Statins reduce cardiovascular mortality through the regression of coronary calcification and the reduction of LDL cholesterol levels in patients with dyslipidemia. These hypolipidemic drugs have also been associated to increased bone mineralization in mice [38] and in patients with osteoporosis [39] and with a reduction of fracture incidence. Last, recent clinical studies indicated that beta blockers and antihypertension drugs would reduce the risk of fragility fractures in the elderly population [40]. Moreover, in a rodent model angiotensin II type 1 and 2 receptor blockers (ARB) widely used antihypertensive agents, were shown to enhance bone mass through both the increase of osteoblast activity and the suppression of osteoclast activity [41]. Recently, a preventive effect of angiotensin II type 1 receptor blocker on osteoporosis has been reported but these data need confirmation [42]. The fact that all these drugs are effective on both osteoporosis and CVDs suggests a possible link between vascular and skeletal systems. Therefore, it is priority to establish to what extent treatments for osteoporosis are effective and beneficial for CVDs and vice versa, as well as to comprehend the exact physiopathological mechanisms shared by these diseases.

According to the current knowledge, further specific studies are necessary to better define the relationship between osteoporosis and CVDs and to identify common risk factors and genetic determinants.

\section{Vitamin D Receptor Gene (VDR)}

Since the important role of vitamin $\mathrm{D}$ in the regulation of calcium homeostasis and bone metabolism, vitamin D receptor $(V D R)$ gene has been the first candidate gene to be analyzed in association studies by Morrison at al. in 1994 [43] and it was proposed as a major locus for genetic effects on bone metabolism. Principal analyzed polymorphisms are the BsmI, ApaI, and TaqI polymorphisms in the 3' UTR of the gene, the FokI polymorphism in exon 2 (that creates an alternative initiation traduction codon) and the $C d x 2$ polymorphism in the promoter region of the gene. During the last two decades, several association studies have been performed but with conflicting data. Recent data seem to indicate that association between VDR polymophisms and bone mass is rather weak and the clinical impact of these variants remains unclear. Given the extent of published data on this gene and the non-concording results, interest now focuses on meta-analyses rather than single association studies alone. A haplotype meta-analysis by Thakkinstian et al. [44] evidenced that VDR single polymorphisms were not significantly associated to osteoporosis while Bat and $B A t$ haplotypes were significantly associated, demonstrating the importance of haplotype studies rather than single polymorphism studies.

The Genomos study collected 26,242 Caucasian participants (18,405 women) and evaluated the association between 
Cdx2, FokI, BsmI, ApaI, and TaqI polymorphisms with the DEXA-measure femoral neck and lumbar spine BMD and fractures, concluding that the FokI, BsmI, ApaI, and TaqI polymorphisms are not associated with BMD variation or with fractures while the " $A$ " allele of the $C d \times 2$ polymorphism is associated with a reduced risk of vertebral fractures [45].

VDR is involved in vascular smooth muscle cell growth and in the regulation of calcium homeostasis and could therefore be involved in vascular plaques instability and calcification, thus, VDR polymorphisms may be associated with different risk for CVDs. In a study by Van Shooten et al. [46] the $b b$ genotype of the $V D R$ gene appeared to be predictive of severe coronary artery disease (CAD). The bb genotype is associated with low levels of circulating active form of vitamin D (calcitriol) [43], thus, results from this study seem to agree with previous finding of an inverse association between circulating calcitriol and CAD $[47,48]$. The genetic association between VDR polymorphisms and CAD risk was not confirmed by a study in a Chinese population [49].

\section{Estrogen Receptors Alpha and Beta Genes (ER $\alpha$ and ER $\beta$ )}

Estrogens exert important effects on bone mass acquisition and maintenance. A rare case of a 28-year-old man with estrogen resistance and juvenile osteoporosis due to a nonsense inactivating point mutation in exon 2 of the $E R \alpha$ gene has been described [9]. Patient presented with unfused epiphyses and continuing linear growth in adulthood, indicating that estrogen is important for normal skeletal growth and bone development and mineralization in men as well as women. Genes encoding for estrogen receptors have been widely investigated in osteoporosis association studies. Most studies have focused on the $(\mathrm{TA})_{n}$ repeat microsatellite in the promoter region and on the PvuII and XbaI single nucleotide polymorphisms (SNPs) in the intron 1 of the $E R \alpha$ gene. However, these studies generated conflicting results, suggesting the needing of large-scale investigations and analysis standardization. A meta-analysis by Ioannidis et al. [50] seemed to indicate no significant association between single $E R \alpha$ polymorphisms with $\mathrm{BMD}$, while a significant reduction of fracture risk was associated to the $X X$ genotype. Conversely, when $E R \alpha$ polymorphisms are analyzed together as haplotypes [51], significant associations of haplotypes with spinal BMD, decreased vertebral spine bone area and increased risk for spinal fracture were found in women, but not in men. This study also evidenced that ER $\alpha$-dependent fracture risk is independent of BMD and bone area.

The Genomos study collected 18917 individuals (14,622 women) and evaluated the association of the three common $E R \alpha$ polymorphisms with the DEXA-measured femoral neck and lumbar spine BMD and with fractures [52]. The study evidenced that $E R \alpha$ polymorphisms exert only small effects on BMD. Conversely, the $X X$ genotype resulted to be associated with a $20 \%$ reduction in fracture risk by mechanisms independent of BMD.
However, to date most association studies on $E R \alpha$ gene have evaluated the association of its polymorphisms with BMD and fracture risk but not with bone structural and geometric properties. Recently, Cepollaro et al. [53] have evaluated the influence of $\mathrm{XbaI}$ and $\mathrm{PvuII}$ polymorphisms on structural and geometric bone parameters assessed by pQCT at the tibia in 541 Italian women and 449 Italian men. The study evidenced a significant association between the $P P$ genotype of PvuII and higher values of tibial cortical thickness in male subjects. This result indicated a role for $E R \alpha$ gene in the control of tibia bone geometry and could explain the mechanism by which $E R \alpha$ gene polymorphisms influence fracture risk independently of BMD.

$E R \beta$ gene has been less studied in osteoporosis association studies since its role on bone metabolism is not yet completely known. ER $\beta$ seems to have a role in mediating estrogen effect on bone growth and bone size but not on $\mathrm{BMD}[54] . \mathrm{A}(\mathrm{CA})_{n}$ repeat microsatellite polymorphism in the promoter region has been associated with BMD in Asian $[55,56]$ and Caucasian [57] populations. No meta-analysis of $E R \beta$ association studies is available so far.

Estrogens have vasodilatatory, antiinflammatory and antiproliferative effects on the cardiovascular system and they have been reported to provide protection against CAD in postmenopausal women [58]. Lu et al. [59] associated the novel $-1989 \mathrm{~T} / \mathrm{G}$ polymorphism in the $E R \alpha$ promoter $\mathrm{B}$ with CAD risk, concluding that the G/G genotype may be an independent predictor for CAD in patients with familiar hypercholesterolemia. In addition, they found that the long number $(>17)$ of $(\mathrm{TA})_{n}$ repeat in the $E R \alpha$ promoter region was significantly higher in postmenopausal women with CAD than in those without CAD, but not in men. Pollak et al. [60] confirmed this result and found an association between homozygote genotype for long alleles (>18) and a significantly higher angiographic severity of CAD in young patients. Alevizaki et al. [61] found that ER $\alpha$ PuII and $X b a I$ polymorphisms may influence the severity of CAD in women, associating the $\mathrm{C}$ allele of PvuII and the $\mathrm{G}$ allele of $X b a I$ with a higher number of arteries with a significant stenosis in the coronary angiography.

\section{Collagen Type I $\alpha 1$ Gene (COLIAI)}

COLI1A1 gene encodes for the $\alpha 1$ chain of collagen type I that is the principal proteic component of bone extracellular matrix, thus, this gene is an important candidate for osteoporosis risk. Several association studies have been conducted on a polymorphism in intron 1, a G/T substitution that creates a binding site for the transcription factor $S p 1$. The ss (T/T) genotype has been associated with reduced BMD [62, 63], increased age-related bone loss $[64,65]$, increased femoral neck angle [66], an impaired ability of osteoblast-like cells to form mineralized bone nodules in vitro and with abnormalities of bone mineralization in vivo [67] and a higher risk of fracture due to altered bone density and quality [68]. In general, association studies on this gene demonstrated a positive correlation between SS $(\mathrm{G} / \mathrm{G})$ genotype and reduced fracture risk even with lack of 
association with BMD values. A meta-analysis evidenced that different Sp1 alleles are associated with modest variation in BMD but with significant changes in fracture risk [69]. The $\mathrm{T}$ allele is associated with an abnormally increased synthesis of collagen I $\alpha 1$ chain generating an imbalance between the $\alpha 1$ and $\alpha 2$ chains and a reduction of bone strength and bone matrix mineralization [67].

The Genomos study collected standardized data on 20,786 individuals and evaluated association of the Sp1 polymorphism with the DEXA-measured femoral neck and lumbar spine BMD and with fractures [70]. The $s$ allele resulted to be associated with recessive-inherited reduced BMD. However, this association was quite weak. Authors also found a modest association of the $s$ allele with vertebral fractures, particularly in women, and hypothesized that this allele could predispose to incidental vertebral fractures independently of BMD.

\section{Transforming Growth Factor $\beta 1$ (TGF $\beta 1)$}

TGF $\beta$ lgene encodes a local growth factor that is widely expressed by bone cells and it is involved in the regulation of bone turnover [71-73]. This gene has been analyzed as a possible osteoporosis candidate gene; principal investigated polymorphisms are located in the promoter region $(-1348 \mathrm{C} / \mathrm{T}$ and $-509 \mathrm{C} / \mathrm{T})$ and in the exon $1(29 T / C$ Leu10Pro and 74G/C Arg25Pro). Several studies have associated variants in this gene with BMD variation and/or fragility fractures risk [74-80], but none of them have investigated the effects of TGF $\beta 1$ haplotypes.

The Genomos study performed a wide standardized analysis including 28924 participants from 10 European centers [81]. The study genotyped five polymorphisms of TGF $\beta 1$ gene (two located in the promoter region, two located in the exon 1 and one located in exon 5) and associated them with DEXA-measured BMD of lumbar spine and femoral neck and with fractures. None of the polymorphisms or haplotypes resulted to be associated to BMD variations or to affect the overall risk of fractures. A weak association was detected between carriers of the rare $788 \mathrm{~T}$ allele of the 788 C/T polymorphism (Thr263Ile) in exon 5 and the risk of incident vertebral fractures.

TGF $\beta$ seems to have contrasting functions on cardiovascular system. Some studies reported a protective effect of TGF $\beta$ by reducing the risk of CVDs [82-85], while others described TGF $\beta$ as inducing or facilitating CVDs such as vascular stenosis and thrombogenesis [86, 87]. The Arg25Pro polymorphism in exon 1 has been associated with different risk of essential hypertension in Russian male individuals [88], with variation in systemic blood pressure in essential hypertensive patients [89] and with different risk of myocardial infarction or hypertension in Caucasian patients [90], but no correlation has been found between this polymorphism and the risk of myocardial infarction and stroke [91], the risk of CAD in Caucasian patients [92] and with the severity of CAD and the occurrence of myocardial infarction or hypertension in Australian patients [93]. The Leu10Pro polymorphism in exon 1 has been associated with susceptibility to myocardial infarction in a Japanese population [94], with clinical characteristics of hypertension [95] and with the risk of stroke in an elderly Caucasian population [91], but not with the risk of myocardial infarction in the same elderly Caucasian population [91].

\section{Low-Density Lipoprotein Receptor-Related Protein 5 and 6 (LRP5 and LRP6)}

LRP5 and its related homologue LRP6 are cell-membrane coreceptors for Wnt proteins an the Wnt/beta catenin signalin pathway, that controls osteoblast activity and bone formation. LRP5 gene has a clear role in rare bone diseases and also in normal variation in peak BMD.

Inactivating mutations of LRP5 lead to osteoporosis pseudoglyoma [96] while activating mutations result in high bone mass phenotypes [97, 98].

Point mutations in LRP6 gene cause abnormal formation of the axial skeleton and a low bone mass phenotype in mice [99].

Thus, common variants in LRP5 and LRP6 genes may contribute to normal population variance in human bone metabolism, and these two genes have been recently proposed and analyzed as putative osteoporosis candidate genes. Two studies $[100,101]$ have demonstrated an association between LRP5 variants and bone mass in human populations. Particularly, Ferrari et al. [100] found an association between 2047 G/A substitution (Val667Met) in exon 9 and bone mineral content at lumbar spine, bone area and with stature in men, but not in women.

A study by van Meurs et al. [102] analyzed the role of four variants of the LRP5 gene and one aminoacid variant of the LRP6 gene in determining BMD, bone geometry and fracture risk. Authors found that the 1330 Val allele (Ala1330 Val polymorphism) of the LRP5 gene was associated with a decreased BMD at lumbar spine and femoral neck and with reduced vertebral body size and femoral neck width in men. Male carriers of the $1330 \mathrm{Val}$ allele had a $60 \%$ increased risk for fragility fractures. A borderline association of the LRP6 Ile1062 Val polymorphism with height and vertebral body size was observed in men. Males carriers of the $1062 \mathrm{Val}$ allele had a $60 \%$ higher risk of fractures. In women all these association were weaker than in men.

All these studies indicated that LRP5 and LRP6 associations with bone phenotypes are sex specific.

The Genomos study collected and analyzed 37,534 Caucasian individuals from Europe and North America and associated DEXA-measured BMD at lumbar spine and femoral neck and fracture risk with Val667Met and Ala1330Val polymorphisms of the LRP5 gene and with Ile1062 Val polymorphism of the LRP6 gene [103]. The Met667 and Val1330 alleles were both associated with reduced spinal and femoral BMD and with increased risk of vertebral or total fractures. Haplotype analysis indicated that Met667 and Val1330 variants affected BMD independently. Conversely, the LRP6 Ile1062 Val polymorphism was not associated with any osteoporotic phenotype. 
No studies on the association of LRP5 and LRP6 polymorphisms with CVDs risk are available so far.

\section{Aromatase Gene (CYP19A1)}

Aromatase enzyme catalyses the conversion of androgens to estrogens. Inactivating mutations of the CYP19A1 gene have been associated, in both sexes, with an increased bone turnover and consequently with a decreased BMD [8].

A microsatellite tetranucleotide (TTTA) ${ }_{n}$ repeat polymorphism in intron 4 was associated to osteoporosis risk [104]. Analysis of polymorphism in a postmenopausal cohort of Italian women associated the (TTTA) 12 allele with a protective action versus osteoporosis development. Women with high number of repeats $(>11)$ showed higher lumbar $\mathrm{BMD}$ values than women with low number of repeats (from 8 to 11). However, the molecular mechanism that can explain association between aromatase activity and (TTTA) ${ }_{n}$ repeat is still unknown.

Aromatase has been hypothesized as one of the factor affecting blood pressure and maybe a susceptibility gene for hypertension. A study by Shimodaira et al. [105] found an association between the rs700518 and rs10046 polymorphism, as well as a haplotype constructed with rs1870049 and rs10046 polymorphisms, of CYP19A1 gene with variation in systolic blood pressure and diastolic blood pressure. Interestingly, the at risk genotypes of rs700518 and rs 10046 showed a sex-dependent inverse relationship, suggesting the possibility to use them as genetic markers for gender-specific essential hypertension risk. Ramirez-lorca et al. [106] confirmed that the rs 10046 polymorphism may be involved in the genetic regulation of blood pressure in women. Another study by Letonja et al. [107] concluded that in Caucasian subjects the (TTTA) ${ }_{n}$ repeat polymorphism does not contribute to the genetic susceptibility to CAD.

\section{Insulin-Like Growth Factor I Gene (IGF-1)}

IGF-1 exerts anabolic effects on BMD increasing synthesis of collagen type I and osteocalcin and stimulating alkaline phosphatase activity that results on both proliferation and differentiation of osteoblasts. It is an essential factor during childhood and adulthood in the regulation of trabecular and cortical bone formation.

Association studies evaluated a $(\mathrm{CA})_{n}$ repeat in the promoter region of the gene but with controversial results. The presence of the 194-bp allele has been associated to higher BMD and increased level of circulating IGF-1 in osteoporotic Korean women with respect to healthy controls [108]. Low levels of IGF-1 and a reduced BMD were associated to the homozygote $192 \mathrm{bp}$ allele in men with idiopatic osteoporosis [109] and in Caucasian postmenopausal women [110]. However, a study on Japanese postmenopausal women [111], a study on premenopausal Chinese women [112], and a study on premenopausal Caucasian and Afro-American sibling pairs [113] did not confirm the precedent results.

\section{Interleukin 6 (IL6)}

After menopause the increase of IL6 and other proinflammatory cytokines production related to the estrogen decrease has been associated to the extent of bone loss [114]. The IL6 gene locus (7p21) has been associated with BMD variations in postmenopausal women [115]. Two polymorphisms $(-572 \mathrm{G} / \mathrm{C}$ and $-174 \mathrm{G} / \mathrm{C})$ in the promoter region of the IL6 gene have been associated to markers of bone resorption in postmenopausal women [116, 117]. A study of Ferrari et al. [118] evidenced that the G/G genotype of the $-174 G / C$ polymorphism was associated to a lower BMD with respect to the $\mathrm{G} / \mathrm{C}$ and $\mathrm{C} / \mathrm{C}$ genotypes in over 15 -year postmenopausal women but not in premenopausal women and in men. These results seem demonstrate that IL6 polymorphisms regulate bone mass only after menopause with a molecular mechanism dependent on the estrogen deficiency.

IL6 is a key mediator of inflammation and it has been demonstrated to play an important role in the pathogenesis of atherosclerosis and vascular diseases. Elevated concentrations of IL6 are predictive of future coronary events in healthy individuals and of mortality in patients with acute coronary disease. The $-174 \mathrm{G} / \mathrm{C}$ polymorphism in the promoter region has been associated with variation in IL6 production. Several studies have demonstrated that this polymorphism is associated with risk of coronary hearth disease in men [119-122], with the risk of ischemic carebrovascular events [123], with carotid artery compliance, systolic and diastolic blood pressure and serum highdensity lipoprotein cholesterol in men [124], ischaemic stroke [125], number of severely stenosed coronary arteries [126]. However, despite of numerous studies the role of this polymorphism as a risk factor for CVDs remains inconsistent $[127,128]$ and needs for further researches.

\section{Other Candidate Genes}

Other osteoporosis candidate genes have been studied even if less extensively and with less conclusive results. They include calcitonin receptor (CTR) [129-133], calcium sensing receptor gene (CaSR) [134-136], androgen receptor $(A R)$ [137], parathyroid hormone receptor (PTHR1) [138], sclerotin (SOST) [139], bone morphogenetic protein 2 (BMP2) [140], osteoprotegerin $(O P G)[141,142]$, and so forth. All these gene require confirmation on larger cohorts.

\section{Genome-Wide Association Studies}

The complete sequencing of human genome [143], the results of the HapMap project [144] and the development of novel chip technologies have opened novel avenues for the identification of genetic loci, genes and/or polymorphisms associated with complex diseases such as osteoporosis, through the application of genome-wide association analyses. This approach has permitted the simultaneous analysis of hundreds loci/genes along the human genome and the identification of novel osteoporosis subsceptibility loci 
TABLE 3: QTLs identified and replicated in genome-wide linkage studies for osteoporosis [145]. Asterisks indicate genetic region associated also to clinical CVD events through genome-wide association studies [147].

\begin{tabular}{|c|c|c|}
\hline $\begin{array}{l}\text { QTLs replicated } \\
\text { in at least two } \\
\text { studies }\end{array}$ & $\begin{array}{l}\text { QTLs replicated in } \\
\text { at least three } \\
\text { studies }\end{array}$ & $\begin{array}{l}\text { QTLs replicated in } \\
\text { at least five studies }\end{array}$ \\
\hline$-2 p 21-24$ & $-13 q 31-34$ & $-1 p 36$ \\
\hline - 2q33-37* & $-17 p 11-13$ & $-1 q 21-24$ \\
\hline$-3 q 12-26$ & & $-4 q 31-34$ \\
\hline$-4 p 15-16$ & & $-12 q 23-24^{*}$ \\
\hline$-5 q 33-35$ & & \\
\hline$-6 p 21$ & & \\
\hline - 8q24-qter & & \\
\hline$-10 q 26$ & & \\
\hline - 11q23-24 & & \\
\hline$-14 q 12-24$ & & \\
\hline$-14 q 31-32$ & & \\
\hline$-16 \mathrm{p} 13$ & & \\
\hline - 19p13-q13 & & \\
\hline - 21q22-qter* & & \\
\hline
\end{tabular}

and/or genes that were not candidates based on the current knowledge of the phatophysiology of bone metabolism and osteoporosis. Over 60 quantitative trait loci (QTLs) have been associated with bone metabolism and they were located in all but chromosome Y [145]. A list of genetic loci identified to be linked to bone metabolism through genome-wide approaches, and replicated in at least two different studies, are reported in Table 3. The first osteoporosis genome-wide association study [146] associated 100,000 SNPs with BMD values, bone ultrasound properties and hip geometry index. Some weak associations with genetic markers within or near known osteoporosis candidate genes (i.e., $E R \alpha, C Y P 19$, COLIA1, and LRP5) were detected.

Particularly, the application of genome-wide association scan has allowed the identification of bone morphogenetic protein 2 (BMP2) as a candidate gene for osteoporosis, through the analysis of 207 osteoporotic families (1323 individuals) in Iceland and the subsequent followup association analysis [140]. Recently, also the latent transforming growth factor beta binding protein 2 (LTBP2) [148] and the signal transducer and the activator of transcription 1 (STAT1) [149] genes have been associated with osteoporotic phenotypes.

Given the extensive number of identified candidate loci to date, and given the potential large number of genes within these loci, the next step will be the refinement of the significant loci and the identification of putative candidate genes. Novel identified candidate genes have to be confirmed by follow-up population-based association studies and functional studies. Caution should be taken in the interpretation of replication/confirmation of the results since some genomic region could eventually be proven to be a false positive.
The past few years have seen a significant increase in the number of genetic loci associated with CVDs through genome-wide association studies. Significant results have been reported in a recent review [147].

\section{Animal Models}

Comparative genetics is helpful in the comprehension of molecular mechanisms of bone remodeling and in the searching for osteoporosis candidate genes. Studies in animals are essential because they allow breeding strategies that cannot be performed in humans and they also provided extreme bone strength phenotypes that cannot be measured in vivo in humans. Rodents and primates are the most suitable models. Linkage studies in rats [150], mice $[151,152]$ and primates [153] have permitted the identification of numerous QTLs that regulate BMD and other bone quality properties (shape, microstructure and strength). Particularly, linkage analysis in mouse has allowed the identification of Alox 15 gene as a negative regulator of BMD. The Alox15-knock-out mice presented an increased BMD and the inhibition of Alox 15 expression compensated the ovariectomy-induced bone loss [154]. Recent studies have shown that genetic variations in a human homologue of Alox15 (ALOX12) accounted for approximately 3\% of the bone mass variation in humans $[155,156]$. Moreover, the using of knock-out and transgenic animal models for the study of bone monogenic diseases has helped in the identification of biologically relevant osteoporosis candidate genes for association studies. These approaches also helped in delivering biological function of a specific gene in bone metabolism. An example is the LRP5 gene whose activating or inactivating mutations have been demonstrated to be responsible for opposite extreme bone phenotypes [10, 9698], using specific $L R P 5$-mutated animal models.

\section{Future Perspectives: the Pharmacogenetics of Osteoporosis}

A very novel area of the genetics of osteoporosis is the pharmacogenetics of osteoporosis. Pharmacogenetics is the application of genetic studies to predict the outcome of drug treatments with respect to both beneficial and adverse events, and it is particularly important in chronic diseases, such as osteoporosis, that require long-term drug treatments and for which alternative effective drug therapies are available. Potentially pharmacogenetics of osteoporosis will allow clinicians to choose in advance the best treatment and the most effective drug regimen based on patient genotype. However, to date only few studies on the pharmacogenetics of osteoporosis have been published and no clinical applications are available. Pharmacogenetic studies associated osteoporosis candidate genes (VDR, ER $\alpha, E R \beta$, and COLIA1) with the response to antiresorptive and antifracture agents such as hormone replacement therapy, raloxifene and bisphosphonates [157] and found weak associations. Recently a study by our Research Group [158] associated the A/C rs2297480 
polymorphism of the FDPS gene with the response to aminobisphosphonates in a cohort of Danish osteoporotic women.

All these studies suggested the possibility to use genetic screening to tailor decisions about osteoporosis antifracture treatment choice; however, all these preliminary data need to be confirmed and validated by large-scale studies, by prospective well-designed clinical trials and by functional analyses.

Data from studies on pharmacogenetics of osteoporosis would be useful also in the field of CVDs since there are scientific evidences of the positive action of antiresorptive drugs, such as bisphosphonates and raloxifene, on the reduction of CVDs risk [22, 31-33].

\section{Conclusions}

The contribution of genetic factors to age-related chronic diseases such as osteoporosis and CVDs is important. The identification of genes that contribute to the pathogenesis of such disorders has potential public health, clinic and therapeutic implications. However, since osteoporosis is a complex multifactorial disease, the association studies performed to date presented with non-concluding or conflicting results. Now it is clear that a single SNP exerts less than $1-3 \%$ of effect in the determination of bone metabolism. Only large-scale standardized studies in wellcharacterized and homogenous populations and the study of haplotypes and/or multiple SNPs and/or genes might help in a better understanding of genetic factors underlying bone phenotypes heritability and calcium and lipid metabolism regulation. Moreover, technological advances such as genome-wide association scan will help in identifying novel candidate loci and/or genes, in validating the role of candidate gene polymorphisms and in analyzing hundreds of SNPs simultaneously.

However, genetic epidemiology association studies did not tell how genes contribute to the disease, thus, functional genomic studies, large-scale gene expression studies and proteomic studies are fundamental for the comprehension of molecular and cellular mechanisms regulating bone and cardiovascular pathophysiology. The aim of functional genetics is not only to collect information about single gene functions but also to understand how biological component work together to regulate bone metabolism and cardiovascular system functionality. The great challenge of genetics of osteoporosis and cardiovascular diseases will be not only identifying the responsible genes but also understanding how these genes act and how they are influenced by other biological and/or environmental factors.

\section{Acknowledgments}

This work was supported by a grant of the Fondazione Ente Cassa di Risparmio di Firenze and F.I.R.M.O. Fondazione Raffaella Becagli to the second author. F. Marini, Ph.D., is the recipient of the Amgen-Dompè fellowship, dedicated to Professor Isa Coghi from Osservatorio Nazionale Salute Donna (O.N.Da).

\section{References}

[1] E. A. Krall and B. Dawson-Hughes, "Heritable and life-style determinants of bone mineral density," Journal of Bone and Mineral Research, vol. 8, no. 1, pp. 1-9, 1993.

[2] R. Guéguen, P. Jouanny, F. Guillemin, C. Kuntz, J. Pourel, and G. Siest, "Segregation analysis and variance components analysis of bone mineral density in healthy families," Journal of Bone and Mineral Research, vol. 10, no. 12, pp. 2017-2022, 1995.

[3] T. L. Stewart and S. H. Ralston, "Role of genetic factors in the pathogenesis of osteoporosis," Journal of Endocrinology, vol. 166, no. 2, pp. 235-245, 2000.

[4] H.-W. Deng, W.-M. Chen, S. Recker, et al., "Genetic determination of Colles' fracture and differential bone mass in women with and without Colles' fracture," Journal of Bone and Mineral Research, vol. 15, no. 7, pp. 1243-1252, 2000.

[5] T. Andrew, L. Antioniades, K. J. Scurrah, A. J. MacGregor, and T. D. Spector, "Risk of wrist fracture in women is heritable and is influenced by genes that are largely independent of those influencing BMD," Journal of Bone and Mineral Research, vol. 20, no. 1, pp. 67-74, 2005.

[6] N. K. Arden, J. Baker, C. Hogg, K. Baan, and T. D. Spector, "The heritability of bone mineral density, ultrasound of the calcaneus and hip axis length: a study of postmenopausal twins," Journal of Bone and Mineral Research, vol. 11, no. 4, pp. 530-534, 1996.

[7] P. Garnero, N. K. Arden, G. Griffiths, P. D. Delmas, and T. D. Spector, "Genetic influence on bone turnover in postmenopausal twins," Journal of Clinical Endocrinology and Metabolism, vol. 81, no. 1, pp. 140-146, 1996.

[8] A. Morishima, M. M. Grumbach, E. R. Simpson, C. Fisher, and K. Qin, "Aromatase deficiency in male and female siblings caused by a novel mutation and the physiological role of estrogens," Journal of Clinical Endocrinology and Metabolism, vol. 80, no. 12, pp. 3689-3698, 1995.

[9] E. P. Smith, J. Boyd, G. R. Frank, et al., "Estrogen resistance caused by a mutation in the estrogen-receptor gene in a man," The New England Journal of Medicine, vol. 331, no. 16, pp. 1056-1061, 1994.

[10] E. R. Barros, M. R. Dias da Silva, I. S. Kunii, O. M. Hauache, and M. Lazaretti-Castro, "A novel mutation in the LRP5 gene is associated with osteoporosis-pseudoglioma syndrome," Osteoporosis International, vol. 18, no. 7, pp. 1017-1018, 2007.

[11] S. Carbonell Sala, L. Masi, F. Marini, et al., "Genetics and pharmacogenetics of osteoporosis," Journal of Endocrinological Investigation, vol. 28, supplement 10, pp. 2-7, 2005.

[12] S. Carbonell Sala and M. L. Brandi, "Genetic determinants of osteoporosis," Medicografia, vol. 29, pp. 180-184, 2007.

[13] S. H. Ralston, "Genetics of osteoporosis: symposium on 'genetic polymorphisms and disease risk', Proceedings of the Nutrition Society, vol. 66, no. 2, pp. 158-165, 2007.

[14] F. M. K. Williams and T. D. Spector, "Recent advances in the genetics of osteoporosis," Journal of Musculoskeletal Neuronal Interactions, vol. 6, no. 1, pp. 27-35, 2006.

[15] T. Andrew and A. J. Macgregor, "Genes and osteoporosis," Current Osteoporosis Reports, vol. 2, no. 3, pp. 79-89, 2004.

[16] P. Pennisi, S. S. Signorelli, S. Riccobene, et al., "Low bone density and abnormal bone turnover in patients with atherosclerosis of peripheral vessels," Osteoporosis International, vol. 15, no. 5, pp. 389-395, 2004.

[17] D. P. Kiel, L. I. Kauppila, L. A. Cupples, M. T. Hannan, C. J. O'Donnell, and P. W. F. Wilson, "Bone loss and 
the progression of abdominal aortic calcification over 25 year period: the Framingham Heart Study," Calcified Tissue International, vol. 68, no. 5, pp. 271-276, 2001.

[18] P. von der Recke, M. A. Hansen, and C. Hassager, "The association between low bone mass at the menopause and cardiovascular mortality," American Journal of Medicine, vol. 106, no. 3, pp. 273-278, 1999.

[19] P. A. Marcovitz, H. H. Tran, B. A. Franklin, et al., "Usefulness of bone mineral density to predict significant coronary artery disease," American Journal of Cardiology, vol. 96, no. 8, pp. 1059-1063, 2005.

[20] P. Collin-Osdoby, "Regulation of vascular calcification by osteoclast regulatory factors RANKL and osteoprotegerin," Circulation Research, vol. 95, no. 11, pp. 1046-1057, 2004.

[21] F. Ikeda, R. Nishimura, T. Matsubara, et al., "Critical roles of c-Jun signaling in regulation of NFAT family and RANKLrequlated osteoclast differentiation," Journal of Clinical Investigation, vol. 114, no. 4, pp. 475-484, 2004.

[22] S. I. McFarlane, R. Muniyappa, J. J. Shin, G. Bahtiyar, and J. R. Sowers, "Osteoporosis and cardiovascular disease: brittle bones and boned arteries, is there a link?" Endocrine, vol. 23, no. 1, pp. 1-10, 2004.

[23] T. Yamaguchi, T. Sugimoto, S. Yano, et al., "Plasma lipids and osteoporosis in postmenopausal women," Endocrine Journal, vol. 49, no. 2, pp. 211-217, 2002.

[24] P. Strazzullo, V. Nunziata, M. Cirillo, et al., "Abnormalities of calcium metabolism in essential hypertension," Clinical Science, vol. 65, no. 2, pp. 137-141, 1983.

[25] F. P. Cappuccio, E. Meilahn, J. M. Zmuda, and J. A. Cauley, "High blood pressure and bone-mineral loss in elderly white women: a prospective study," The Lancet, vol. 354, no. 9183, pp. 971-975, 1999.

[26] A. Hvarfner, R. Bergström, C. Mörlin, L. Wide, and S. Ljunghall, "Relationships between calcium metabolic indices and blood pressure in patients with essential hypertension as compared with a healthy population," Journal of Hypertension, vol. 5, no. 4, pp. 451-456, 1987.

[27] Y. Izawa, K. Sagara, T. Kadota, and T. Makita, "Bone disorders in spontaneously hypertensive rat," Calcified Tissue International, vol. 37, no. 6, pp. 605-607, 1985.

[28] M. Cirillo, F. Galetti, P. Strazzullo, L. Torielli, and M. C. Melloni, "On the pathogenetic mechanism of hypercalciuria in genetically hypertensive rats of the Milan strain," American Journal of Hypertension, vol. 2, no. 10, pp. 741-746, 1989.

[29] D. E. Grobbee, H. Burger, A. Hofman, and H. A. Pols, "Blood pressure and bone density are inversely related in the elderly," Journal of Hypertension, vol. 14, supplement 11, p. S35, 1996.

[30] J. Tsuda, I. Nishio, and Y. Masuyama, "Is hypertension a risk factor for osteoporosis? Dual energy X-ray absorptiometric investigation," Journal of Hypertension, vol. 16, supplement 2, p. S209, 1998.

[31] V. Baldini, M. Mastropasqua, C. M. Francucci, and E. D'Erasmo, "Cardiovascular disease and osteoporosis," Journal of Endocrinological Investigation, vol. 28, supplement 10, pp. 69-72, 2005.

[32] J. R. Burnett and S. D. Vasikaran, "Cardiovascular disease and osteoporosis: is there a link between lipids and bone?" Annals of Clinical Biochemistry, vol. 39, no. 3, pp. 203-210, 2002.

[33] C. F. Danilevicius, J. B. Lopes, and R. M. R. Pereira, "Bone metabolism and vascular calcification," Brazilian Journal of Medical and Biological Research, vol. 40, no. 4, pp. 435-442, 2007.
[34] P. A. Price, S. A. Faus, and M. K. Williamson, "Bisphosphonates alendronate and ibandronate inhibit artery calcification at doses comparable to those that inhibit bone resorption," Arteriosclerosis, Thrombosis, and Vascular Biology, vol. 21, no. 5, pp. 817-824, 2001.

[35] B. W. Walsh, L. H. Kuller, R. A. Wild, et al., "Effects of raloxifene on serum lipids and coagulation factors in healthy postmenopausal women," Journal of the American Medical Association, vol. 279, no. 18, pp. 1445-1451, 1998.

[36] A. Saitta, D. Altavilla, D. Cucinotta, et al., "Randomized, double-blind, placebo-controlled study on effects of raloxifene and hormone replacement therapy on plasma NO concentrations, endothelin-1 levels, and endotheliumdependent vasodilation in postmenopausal women," Arteriosclerosis, Thrombosis, and Vascular Biology, vol. 21, no. 9, pp. 1512-1519, 2001.

[37] E. Barrett-Connor, D. Grady, A. Sashegyi, et al., "Raloxifene and cardiovascular events in osteoporotic postmenopausal women: four-year results from the MORE (Multiple Outcomes of Raloxifene Evaluation) randomized trial," Journal of the American Medical Association, vol. 287, no. 7, pp. 847857, 2002.

[38] G. Mundy, R. Garrett, S. Harris, et al., "Stimulation of bone formation in vitro and in rodents by statins," Science, vol. 286, no. 5446, pp. 1946-1949, 1999.

[39] C. J. Edwards, D. J. Hart, and T. D. Spector, "Oral statins and increased bone-mineral density in postmenopausal women," The Lancet, vol. 355, no. 9222, pp. 2218-2219, 2000.

[40] H. Lynn, T. Kwok, S. Y. S. Wong, J. Woo, and P. C. Leung, "Angiotensin converting enzyme inhibitor use is associated with higher bone mineral density in elderly Chinese," Bone, vol. 38, no. 4, pp. 584-588, 2006.

[41] Y. Izu, F. Mizoguchi, A. Kawamata, et al., "Angiotensin II type 2 receptor blockade increases bone mass," Journal of Biological Chemistry, vol. 284, no. 8, pp. 4857-4864, 2009.

[42] K. Iijima, "ARB and anti-aging," Nippon Rinsho, vol. 67, pp. 826-834, 2009 (Japanese).

[43] N. A. Morrison, J. C. Qi, A. Tokita, et al., "Prediction of bone density from vitamin D receptor alleles," Nature, vol. 367, no. 6460, pp. 284-287, 1994.

[44] A. Thakkinstian, C. D'Este, J. Eisman, T. Nguyen, and J. Attia, "Meta-analysis of molecular association studies: vitamin D receptor gene polymorphisms and BMD as a case study," Journal of Bone and Mineral Research, vol. 19, no. 3, pp. 419428, 2004.

[45] A. G. Uitterlinden, S. H. Ralston, M. L. Brandi, et al., "The association between common vitamin D receptor gene variations and osteoporosis: a participant-level metaanalysis," Annals of Internal Medicine, vol. 145, no. 4, pp. 255264, 2006.

[46] F. J. Van Schooten, A. Hirvonen, L. M. Maas, et al., "Putative susceptibility markers of coronary artery disease: association between VDR genotype, smoking, and aromatic DNA adduct levels in human fight atrial tissue," FASEB Journal, vol. 12, no. 13, pp. 1409-1417, 1998.

[47] R. Scragg, R. Jackson, I. M. Holdaway, T. Lim, and R. Beaglehole, "Myocardial infarction is inversely associated with plasma 25-hydroxyvitamin D3 levels: a communitybased study," International Journal of Epidemiology, vol. 19, no. 3, pp. 559-563, 1990.

[48] J. Stamler, D. Wentworth, and J. D. Neaton, "Is relationship between serum cholesterol and risk of premature death from coronary heart disease continuous and graded?. Findings in 356,222 primary screenees of the Multiple Risk Factor 
Intervention Trial (MRFIT)," Journal of the American Medical Association, vol. 256, no. 20, pp. 2823-2828, 1986.

[49] X.-M. Pan, D.-R. Li, L. Yang, et al., "No association between Vitamin D receptor polymorphisms and coronary artery disease in a Chinese population," DNA and Cell Biology, vol. 28 , no. 10, pp. 521-525, 2009.

[50] J. P. A. Ioannidis, I. Stavrou, T. A. Trikalinos, et al., "Association of polymorphisms of the estrogen receptor alpha gene with bone mineral density and fracture risk in women: a meta-analysis," Journal of Bone and Mineral Research, vol. 17, no. 11, pp. 2048-2060, 2002.

[51] J. B. J. van Meurs, S. C. E. Schuit, A. E. A. M. Well, et al., "Association of $5^{\prime}$ estrogen receptor alpha gene polymorphisms with bone mineral density, vertebral bone area and fracture risk," Human Molecular Genetics, vol. 12, no. 14, pp. 1745-1754, 2003.

[52] J. P. A. Ioannidis, S. H. Ralston, S. T. Bennett, et al., "Differential genetic effects of ESR1 gene polymorphisms on osteoporosis outcomes," Journal of the American Medical Association, vol. 292, no. 17, pp. 2105-2114, 2004.

[53] C. Cepollaro, F. Lauretani, A. Gozzini, et al., "Relationship of volumetric bone mineral density and structural parameters with ERa gene polymorphisms," Calcified Tissue International, vol. 80, no. 5, pp. 307-315, 2007.

[54] S. H. Windahl, O. Vidal, G. Andersson, J. A. Gustafsson, and C. Ohlsson, "Increased cortical bone mineral content but unchanged trabecular bone mineral density in female $E R \beta^{-/-}$ mice," Journal of Clinical Investigation, vol. 104, no. 7, pp. 895-901, 1999.

[55] S. Ogawa, T. Hosoi, M. Shiraki, et al., "Association of estrogen receptor $\beta$ gene polymorphism with bone mineral density," Biochemical and Biophysical Research Communications, vol. 269, no. 2, pp. 537-541, 2000.

[56] H. H. L. Lau, A. Y. Y. Ho, K. D. K. Luk, and A. W. C. Kung, "Estrogen receptor $\beta$ gene polymorphisms are associated with higher bone mineral density in premenopausal, but not postmenopausal southern Chinese women," Bone, vol. 31, no. 2, pp. 276-281, 2002.

[57] J. K. Scariano, S. G. Simplicio, G. D. Montoya, P. J. Garry, and R. N. Baumgartner, "Estrogen receptor $\beta$ dinucleotide (CA) repeat polymorphism is significantly associated with bone mineral density in postmenopausal women," Calcified Tissue International, vol. 74, no. 6, pp. 501-508, 2004.

[58] E. Barrett-Connor, "Sex differences in coronary heart disease: why are women so superior? The 1995 Ancel Keys Lecture," Circulation, vol. 95, no. 1, pp. 252-264, 1997.

[59] H. Lu, T. Higashikata, A. Inazu, et al., "Association of estrogen receptor-alpha gene polymorphisms with coronary artery disease in patients with familial hypercholesterolemia," Arteriosclerosis, Thrombosis, and Vascular Biology, vol. 22, pp. 817-823, 2002.

[60] A. Pollak, A. Rokach, A. Blumenfeld, L. J. Rosen, L. Resnik, and R. D. Pollak, "Association of oestrogen receptor alpha gene polymorphism with the angiographic extent of coronary artery disease," European Heart Journal, vol. 25, no. 3, pp. 240-245, 2004.

[61] M. Alevizaki, K. Saltiki, A. Cimponeriu, et al., "Severity of cardiovascular disease in postmenopausal women: associations with common estrogen receptor a polymorphic variants," European Journal of Endocrinology, vol. 156, no. 4, pp. 489-496, 2007.

[62] S. F. A. Grant, D. M. Reid, G. Blake, R. Herd, I. Fogelman, and S. H. Ralston, "Reduced bone density and osteoporosis associated with a polymorphic Spl binding site in the collagen type I a 1 gene," Nature Genetics, vol. 14, no. 2, pp. 203-205, 1996.

[63] A. G. Uitterlinden, H. Burger, Q. Huang, et al., "Relation of alleles of the collagen type Ial gene to bone density and the risk of osteoporotic fractures in postmenopausal women," The New England Journal of Medicine, vol. 338, no. 15, pp. 1016-1021, 1998.

[64] S. S. Harris, M. S. Patel, D. E. C. Cole, and B. DawsonHughes, "Associations of the collagen type Ia1 Sp1 polymorphism with five-year rates of bone loss in older adults," Calcified Tissue International, vol. 66, no. 4, pp. 268-271, 2000.

[65] H. M. MacDonald, F. A. McGuigan, S. A. New, et al., "COL1A1 Sp1 polymorphism predicts perimenopausal and early postmenopausal spinal bone loss," Journal of Bone and Mineral Research, vol. 16, no. 9, pp. 1634-1641, 2001.

[66] A. M. Qureshi, F. E. A. McGuigan, D. G. Seymour, J. D. Hutchison, D. M. Reid, and S. H. Ralston, "Association between COLIA1 Sp1 alleles and femoral neck geometry," Calcified Tissue International, vol. 69, no. 2, pp. 67-72, 2001.

[67] T. L. Stewart, P. Roschger, B. M. Misof, et al., "Association of COLIA1 Sp1 alleles with defective bone nodule formation in vitro and abnormal bone mineralization in vivo," Calcified Tissue International, vol. 77, no. 2, pp. 113-118, 2005.

[68] V. Mann, E. E. Hobson, B. Li, et al., "A COL1A1 Sp1 binding site polymorphism predisposes to osteoporotic fracture by affecting bone density and quality," Journal of Clinical Investigation, vol. 107, no. 7, pp. 899-907, 2001.

[69] V. Mann and S. H. Ralston, "Meta-analysis of COL1A1 Sp1 polymorphism in relation to bone mineral density and osteoporotic fracture," Bone, vol. 32, no. 6, pp. 711-717, 2003.

[70] S. H. Ralston, A. G. Uitterlinden, M. L. Brandi, et al., "Large-scale evidence for the effect of the COLIA1 Sp1 polymorphism on osteoporosis outcomes: the GENOMOS study," PLoS Medicine, vol. 3, no. 4, article e90, pp. 515-523, 2006.

[71] L. F. Bonewald and G. R. Mundy, "Role of transforming growth factor-beta in bone remodeling," Clinical Orthopaedics and Related Research, vol. 250, pp. 261-276, 1990.

[72] J. Pfeilschifter, S. M. D'Souza, and G. R. Mundy, "Effects of transforming growth factor- $\beta$ on osteoblastic osteosarcoma cells," Endocrinology, vol. 121, no. 1, pp. 212-218, 1987.

[73] C. Chenu, J. Pfeilschifter, G. R. Mundy, and G. D. Roodman, "Transforming growth factor $\beta$ inhibits formation of osteoclast-like cells in long-term human marrow cultures," Proceedings of the National Academy of Sciences of the United States of America, vol. 85, no. 15, pp. 5683-5687, 1988.

[74] B. L. Langdahl, J. Y. Knudsen, H. K. Jensen, N. Gregersen, and E. F. Eriksen, "A sequence variation: 713-8delC in the transforming growth factor-beta 1 gene has higher prevalence in osteoporotic women than in normal women and is associated with very low bone mass in osteoporotic women and increased bone turnover in both osteoporotic and normal women," Bone, vol. 20, no. 3, pp. 289-294, 1997.

[75] Y. Yamada, A. Miyauchi, Y. Takagi, M. Tanaka, M. Mizuno, and A. Harada, "Association of the $\mathrm{C}^{--509} \rightarrow \mathrm{T}$ polymorphism, alone or in combination with the $\mathrm{T}^{869} \rightarrow$ C polymorphism, of the transforming growth factor- $\beta_{1}$ gene with bone mineral density and genetic susceptibility to osteoporosis in Japanese women," Journal of Molecular Medicine, vol. 79, no. 2, pp. 149-156, 2001. 
[76] Y. Yamada, A. Miyauchi, J. Goto, et al., "Association of a polymorphism of the transforming growth factor- $\beta 1$ gene with genetic susceptibility to osteoporosis in postmenopausal Japanese women," Journal of Bone and Mineral Research, vol. 13, no. 10, pp. 1569-1576, 1998.

[77] Y. Yamada, F. Ando, N. Niino, and H. Shimokata, "Transforming growth factor- $\beta 1$ gene polymorphism and bone mineral density," Journal of the American Medical Association, vol. 285, no. 2, pp. 167-168, 2001.

[78] Y. Yamada, "Association of polymorphisms of the transforming growth factor- $\beta 1$ gene with genetic susceptibility to osteoporosis," Pharmacogenetics, vol. 11, no. 9, pp. 765-771, 2001.

[79] Y. Yamada, "Association of a Leu ${ }^{10} \rightarrow$ Pro polymorphism of the transforming growth factor- $\beta 1$ with genetic susceptibility to osteoporosis and spinal osteoarthritis," Mechanisms of Ageing and Development, vol. 116, no. 2-3, pp. 113-123, 2000.

[80] Y. Yamada, T. Hosoi, F. Makimoto, H. Tanaka, Y. Seino, and K. Ikeda, "Transforming growth factor beta- 1 gene polymorphism and bone mineral density in Japanese adolescents," American Journal of Medicine, vol. 106, no. 4, pp. 477-479, 1999.

[81] B. L. Langdahl, A. G. Uitterlinden, S. H. Ralston, et al., "Large-scale analysis of association between polymorphisms in the transforming growth factor beta 1 gene (TGFB1) and osteoporosis: the GENOMOS study," Bone, vol. 42, no. 5, pp. 969-981, 2008.

[82] D. J. Grainger and J. C. Metcalfe, "A pivotal role for TGF$\beta$ in atherogenesis?" Biological Reviews of the Cambridge Philosophical Society, vol. 70, no. 4, pp. 571-596, 1995.

[83] D. J. Grainger, "Transforming growth factor beta and atherosclerosis: so far, so good for the protective cytokine hypothesis," Arteriosclerosis, Thrombosis, and Vascular Biology, vol. 24, no. 3, pp. 399-404, 2004.

[84] J. C. Metcalfe and D. J. Grainger, "Transforming growth factor- $\beta$ and the protection from cardiovascular injury hypothesis," Biochemical Society Transactions, vol. 23, no. 2, pp. 403-406, 1995.

[85] J. Saltis, A. Agrotis, and A. Bobik, "Regulation and interactions of transforming growth factor- $\beta$ with cardiovascular cells: implications for development and disease," Clinical and Experimental Pharmacology and Physiology, vol. 23, no. 3, pp. 193-200, 1996.

[86] S. Nikol, J. M. Isner, J. G. Pickering, M. Kearney, G. Leclerc, and L. Weir, "Expression of transforming growth factor- $\beta 1$ is increased in human vascular restenosis lesions," Journal of Clinical Investigation, vol. 90, no. 4, pp. 1582-1592, 1992.

[87] X. L. Wang, S.-X. Liu, and D. E. L. Wilcken, "Circulating transforming growth factor $\beta 1$ and coronary artery disease," Cardiovascular Research, vol. 34, no. 2, pp. 404-410, 1997.

[88] V. P. Ivanov, M. A. Solodilova, A. V. Polonnikov, et al., "Arg25Pro polymorphism of transforming growth factor- $\beta 1$ and its role in the pathogenesis of essential hypertension in Russian population of the Central Chernozem Region," Bulletin of Experimental Biology and Medicine, vol. 144, no. 1, pp. 66-68, 2007.

[89] P. J. Lijnen, V. V. Petrov, and R. H. Fagard, "Association between transforming growth factor- $\beta$ and hypertension," American Journal of Hypertension, vol. 16, no. 7, pp. 604-611, 2003.

[90] F. Cambien, S. Ricard, A. Troesch, et al., "Polymorphisms of the transforming growth factor- $\beta 1$ gene in relation to myocardial infarction and blood pressure: the etude cas-temoin de l'infarctus du myocarde (ECTIM) study," Hypertension, vol. 28, no. 5, pp. 881-887, 1996.

[91] M. P. S. Sie, A. G. Uitterlinden, M. J. Bos, et al., “TGF- $\beta 1$ polymorphisms and risk of myocardial infarction and stroke: the Rotterdam study," Stroke, vol. 37, no. 11, pp. 2667-2671, 2006.

[92] P. Syrris, N. D. Carter, J. C. Metcalfe, et al., "Transforming growth factor- $\beta 1$ gene polymorphisms and coronary artery disease," Clinical Science, vol. 95, no. 6, pp. 659-667, 1998.

[93] X. L. Wang, A. S. Sim, and D. E. L. Wilcken, "A common polymorphism of the transforming growth factor- $\beta 1$ gene and coronary artery disease," Clinical Science, vol. 95, no. 6, pp. 745-746, 1998.

[94] M. Yokota, S. Ichihara, T.-L. Lin, N. Nakashima, and Y. Yamada, "Association of a T29 $\rightarrow$ C polymorphism of the transforming growth factor- $\beta 1$ gene with genetic susceptibility to myocardial infarction in Japanese," Circulation, vol. 101, no. 24, pp. 2783-2787, 2000.

[95] C. Argano, G. Duro, S. Corrao, et al., "Transforming growth factor $\beta 1$ T29C gene polymorphism and hypertension: relationship with cardiovascular and renal damage," Blood Pressure, vol. 17, no. 4, pp. 220-226, 2008.

[96] Y. Gong, R. B. Slee, N. Fukai, et al., "LDL receptor-related protein 5 (LRP5) affects bone accrual and eye development," Cell, vol. 107, no. 4, pp. 513-523, 2001.

[97] L. M. Boyden, J. Mao, J. Belsky, et al., "High bone density due to a mutation in LDL-receptor-related protein 5," The New England Journal of Medicine, vol. 346, no. 20, pp. 1513-1521, 2002.

[98] R. D. Little, J. P. Carulli, R. G. Del Mastro, et al., "A mutation in the LDL receptor-related protein 5 gene results in the autosomal dominant high-bone-mass trait," American Journal of Human Genetics, vol. 70, no. 1, pp. 11-19, 2002.

[99] C. Kokubu, U. Heinzmann, T. Kokubu, et al., "Skeletal defects in ringelschwanz mutant mice reveal that Lrp6 is required for proper somitogenesis and osteogenesis," Development, vol. 131, no. 21, pp. 5469-5480, 2004.

[100] S. L. Ferrari, S. Deutsch, U. Choudhury, et al., "Polymorphisms in the low-density lipoprotein receptor-related protein 5 (LRP5) gene are associated with variation in vertebral bone mass, vertebral bone size, and stature in whites," American Journal of Human Genetics, vol. 74, no. 5, pp. 866-875, 2004.

[101] T. Mizuguchi, I. Furuta, Y. Watanabe, et al., "LRP5, lowdensity-lipoprotein-receptor-related protein 5 , is a determinant for bone mineral density," Journal of Human Genetics, vol. 49, no. 2, pp. 80-86, 2004.

[102] J. B. J. van Meurs, F. Rivadeneira, M. Jhamai, et al., "Common genetic variation of the low-density lipoprotein receptorrelated protein 5 and 6 genes determines fracture risk in elderly white men," Journal of Bone and Mineral Research, vol. 21, no. 1, pp. 141-150, 2006.

[103] J. B. J. van Meurs, T. A. Trikalinos, S. H. Ralston, et al., "Large-scale analysis of association between LRP5 and LRP6 variants and osteoporosis," Journal of the American Medical Association, vol. 299, no. 11, pp. 1277-1290, 2008.

[104] L. Masi, L. Becherini, L. Gennari, et al., "Polymorphism of the aromatase gene in postmenopausal italian women: distribution and correlation with bone mass and fracture risk," Journal of Clinical Endocrinology and Metabolism, vol. 86, no. 5, pp. 2263-2269, 2001.

[105] M. Shimodaira, T. Nakayama, N. Sato, et al., "Association study of aromatase gene (CYP19A1) in essential 
hypertension," International Journal of Medical Sciences, vol. 5, no. 1, pp. 29-35, 2008.

[106] R. Ramirez-Lorca, A. Grilo, M. T. Martinez-Larrad, et al., "Sex and body mass index specific regulation of blood pressure by CYP19A1 gene variants," Hypertension, vol. 50, no. 5, pp. 884-890, 2007.

[107] M. Letonja, B. Peterlin, D. Bregar, and D. Petrovic, "Are the T/C polymorphism of the CYP17 gene and the tetranucleotide repeat (TTTA) polymorphism of the CYP19 gene genetic markers for premature coronary artery disease in Caucasians?” Folia Biologica, vol. 51, no. 3, pp. 76-81, 2005.

[108] J. G. Kim, K. R. Roh, and J. Y. Lee, "The relationship among serum insulin-like growth factor-I, insulinlike growth factor-I gene polymorphism, and bone mineral density in postmenopausal women in Korea," American Journal of Obstetrics and Gynecology, vol. 186, no. 3, pp. 345350, 2002.

[109] C. J. Rosen, E. S. Kurland, D. Vereault, et al., "Association between serum insulin growth factor-I (IGF-I) and a simple sequence repeat in IGF-I gene: implications for genetic studies of bone mineral density," Journal of Clinical Endocrinology and Metabolism, vol. 83, no. 7, pp. 2286-2290, 1998.

[110] F. Rivadeneira, J. J. Houwing-Duistermaat, N. Vaessen, et al., "Association between an insulin-like growth factor I gene promoter polymorphism and bone mineral density in the elderly: the Rotterdam Study," Journal of Clinical Endocrinology and Metabolism, vol. 88, no. 8, pp. 3878-3884, 2003.

[111] M. Miyao, T. Hosoi, S. Inoue, et al., "Polymorphism of insulin-like growth factor I gene and bone mineral density," Calcified Tissue International, vol. 63, no. 4, pp. 306-311, 1998.

[112] D.-K. Jiang, H. Shen, M.-X. Li, et al., "No major effect of the insulin-like growth factor I gene on bone mineral density in premenopausal Chinese women," Bone, vol. 36, no. 4, pp. 694-699, 2005.

[113] I. Takacs, D. L. Koller, M. Peacock, et al., "Sibling pair linkage and association studies between bone mineral density and the insulin-like growth factor I gene locus," Journal of Clinical Endocrinology and Metabolism, vol. 84, no. 12, pp. 44674471, 1999.

[114] C. Scheidt-Nave, H. Bismar, G. Leidig-Bruckner, et al., "Serum interleukin 6 is a major predictor of bone loss in women specific to the first decade past menopause," Journal of Clinical Endocrinology and Metabolism, vol. 86, no. 5, pp. 2032-2042, 2001.

[115] K. Tsukamoto, H. Yoshida, S. Watanabe, et al., "Association of radial bone mineral density with CA repeat polymorphism at the interleukin 6 locus in postmenoposal Japanese women," Journal of Human Genetics, vol. 44, no. 3, pp. 148-151, 1999.

[116] R. E. Murray, F. Mcguigan, S. F. A. Grant, D. M. Reid, and S. H. Ralston, "Polymorphisms of the Interleukin- 6 gene are associated with bone mineral density," Bone, vol. 21, no. 1, pp. 89-92, 1997.

[117] S. L. Ferrari, L. Ahn-Luong, P. Garnero, S. E. Humphries, and S. L. Greenspan, "Two promoter polymorphisms regulating interleukin-6 gene expression are associated with circulating levels of C-reactive protein and markers of bone resorption in postmenopausal women," Journal of Clinical Endocrinology and Metabolism, vol. 88, no. 1, pp. 255-259, 2003.

[118] S. L. Ferrari, P. Garnero, S. Emond, H. Montgomery, S. E. Humphries, and S. L. Greenspan, "A functional polymorphic variant in the interleukin- 6 gene promoter associated with low bone resorption in postmenopausal women," Arthritis and Rheumatism, vol. 44, no. 1, pp. 196-201, 2001.

[119] S. E. Humphries, L. A. Luong, M. S. Ogg, E. Hawe, and G. J. Miller, "The interleukin-6 - 174 G/C promoter polymorphism is associated with risk of coronary heart disease and systolic blood pressure in healthy men," European Heart Journal, vol. 22, no. 24, pp. 2243-2252, 2001.

[120] J.-L. Georges, V. Loukaci, O. Poirier, et al., "Interleukin6 gene polymorphisms and susceptibility to myocardial infarction: the ECTIM study," Journal of Molecular Medicine, vol. 79, no. 5-6, pp. 300-305, 2001.

[121] F. Basso, G. D. O. Lowe, A. Rumley, A. D. McMahon, and S. E. Humphries, "Interleukin-6 - 174 G $>$ C polymorphism and risk of coronary heart disease in West of Scotland coronary prevention study (WOSCOPS)," Arteriosclerosis, Thrombosis, and Vascular Biology, vol. 22, no. 4, pp. 599-604, 2002.

[122] M. Chiappelli, C. Tampieri, E. Tumini, et al., "Interleukin6 gene polymorphism is an age-dependent risk factor for myocardial infarction in men," International Journal of Immunogenetics, vol. 32, no. 6, pp. 349-353, 2005.

[123] W. Lalouschek, M. Schillinger, K. Hsieh, et al., "Polymorphisms of the inflammatory system and risk of ischemic cerebrovascular events," Clinical Chemistry and Laboratory Medicine, vol. 44, no. 8, pp. 918-923, 2006.

[124] J. Hulkkonen, T. Lehtimäki, N. Mononen, et al., "Polymorphism in the IL6 promoter region is associated with the risk factors and markers of subclinical atherosclerosis in men: the Cardiovascular Risk in Young Finns Study," Atherosclerosis, vol. 203, no. 2, pp. 454-458, 2009.

[125] J. Balding, W. J. Livingstone, S. J. Pittock, L. Mynett-Johnson, T. Ahern, and O. P. Smith, "The IL-6 G-174C polymorphism may be associated with ischaemic stroke in patients without a history of hypertension," Irish Journal of Medical Science, vol. 173, no. 4, pp. 200-203, 2004.

[126] J. Myśliwska, J. Wieckiewicz, Ł. Hak, et al., "Interleukin 6 polymorphism corresponds to the number of severely stenosed coronary arteries," European Cytokine Network, vol. 17, no. 3, pp. 181-188, 2006.

[127] M. P. S. Sie, F. A. Sayed-Tabatabaei, H.-H. S. Oei, et al., "Interleukin-6 - $174 \mathrm{G} / \mathrm{C}$ promoter polymorphism and risk of coronary heart disease: results from the Rotterdam study and a meta-analysis," Arteriosclerosis, Thrombosis, and Vascular Biology, vol. 26, no. 1, pp. 212-217, 2006.

[128] B. M. Mayosi, P. J. Avery, M. Baker, et al., "Genotype at the $-174 \mathrm{G} / \mathrm{C}$ polymorphism of the interleukin- 6 gene is associated with common carotid artery intimal-medial thickness: family study and meta-analysis," Stroke, vol. 36, no. 10, pp. 2215-2219, 2005.

[129] M. Miyao, T. Hosoi, M. Emi, et al., "Association of bone mineral density with a dinucleotide repeat polymorphism at the calcitonin (CT) locus," Journal of Human Genetics, vol. 45 , no. 6, pp. 346-350, 2000.

[130] M. Nakamura, Z.-Q. Zhang, L. Shan, et al., "Allelic variants of human calcitonin receptor in the Japanese population," Human Genetics, vol. 99, no. 1, pp. 38-41, 1997.

[131] L. Masi, L. Becherini, L. Gennari, et al., "Allelic variants of human calcitonin receptor: distribution and association with bone mass in postmenopausal Italian women," Biochemical and Biophysical Research Communications, vol. 245, no. 2, pp. 622-626, 1998.

[132] V. Braga, M. Mottes, S. Mirandola, et al., "Association of CTR and COLIA1 alleles with BMD values in peri-and postmenopausal women," Calcified Tissue International, vol. 67, no. 5, pp. 361-366, 2000. 
[133] J. Taboulet, M. Frenkian, J. L. Frendo, N. Feingold, A. Jullienne, and M. C. de Vernejoul, "Calcitonin receptor polymorphism is associated with a decreased fracture risk in post-menopausal women," Human Molecular Genetics, vol. 7, no. 13, pp. 2129-2133, 1998.

[134] K. Tsukamoto, H. Orimo, T. Hosoi, et al., "Association of bone mineral density with polymorphism of the human calcium-sensing receptor locus," Calcified Tissue International, vol. 66, pp. 181-183, 2000.

[135] I. Takács, G. Speer, E. Bajnok, et al., "Lack of association between calcium-sensing receptor gene "A986S" polymorphism and bone mineral density in Hungarian postmenopausal women," Bone, vol. 30, no. 6, pp. 849-852, 2002.

[136] M. Eckstein, I. Vered, S. Ish-Shalom, et al., "Vitamin D and calcium-sensing receptor genotypes in men and premenopausal women with low bone mineral density," Israel Medical Association Journal, vol. 4, no. 5, pp. 340-344, 2002.

[137] B. L. Langdahl, L. Stenkjær, M. Carstens, C. L. Tofteng, and E. F. Eriksen, "A CAG repeat polymorphism in the androgen receptor gene is associated with reduced bone mass and increased risk of osteoporotic fractures," Calcified Tissue International, vol. 73, no. 3, pp. 237-243, 2003.

[138] E. L. Duncan, M. A. Brown, J. Sinsheimer, et al., "Suggestive linkage of the parathyroid receptor type 1 to osteoporosis," Journal of Bone and Mineral Research, vol. 14, no. 12, pp. 1993-1999, 1999.

[139] A. G. Uitterlinden, P. P. Arp, B. W. Paeper, et al., "Polymorphisms in the sclerosteosis/van Buchem disease gene (SOST) region are associated with bone-mineral density in elderly whites," American Journal of Human Genetics, vol. 75, no. 6, pp. 1032-1045, 2004.

[140] U. Styrkarsdottir, J.-B. Cazier, A. Kong, et al., "Linkage of osteoporosis to chromosome 20p12 and association to BMP2," PLoS Biology, vol. 1, no. 3, article E69, 2003.

[141] B. Arko, J. Preželj, R. Komel, A. Kocijančič, P. Hudler, and J. Marc, "Sequence variations in the osteoprotegerin gene promoter in patients with postmenopausal osteoporosis," Journal of Clinical Endocrinology and Metabolism, vol. 87, no. 9, pp. 4080-4084, 2002.

[142] B. L. Langdahl, M. Carstens, L. Stenkjaer, and E. F. Eriksen, "Polymorphisms in the osteoprotegerin gene are associated with osteoporotic fractures," Journal of Bone and Mineral Research, vol. 17, no. 7, pp. 1245-1255, 2002.

[143] J. C. Venter, M. D. Adams, E. W. Myers, et al., "The sequence of the human genome," Science, vol. 291, no. 5507, pp. 13041351, 2001.

[144] W. Zhang, M. J. Ratain, M. E. Dolan, et al., “The HapMap resource is providing new insights into ourselves and its application to pharmacogenomics," Bioinformatics and Biology Insights, vol. 2, pp. 15-23, 2008.

[145] Y.-J. Liu, H. Shen, P. Xiao, et al., "Molecular genetic studies of gene identification for osteoporosis: a 2004 update," Journal of Bone and Mineral Research, vol. 21, no. 10, pp. 1511-1535, 2006.

[146] D. P. Kiel, S. Demissie, J. Dupuis, K. L. Lunetta, J. M. Murabito, and D. Karasik, "Genome-wide association with bone mass and geometry in the framingham heart study," BMC Medical Genetics, vol. 8, supplement 1, article S14, 2007.

[147] D. E. Arking and A. Chakravarti, "Understanding cardiovascular disease through the lens of genome-wide association studies," Trends in Genetics, vol. 25, no. 9, pp. 387-394, 2009.
[148] C.-L. Cheung, P. C. Sham, V. Chan, A. D. Paterson, K. D. K. Luk, and A. W. C. Kung, "Identification of LTBP2 on chromosome $14 \mathrm{q}$ as a novel candidate gene for bone mineral density variation and fracture risk association," Journal of Clinical Endocrinology and Metabolism, vol. 93, no. 11, pp. 4448-4455, 2008.

[149] X.-D. Chen, P. Xiao, S.-F. Lei, et al., "Gene expression profiling in monocytes and SNP association suggest the importance of the STAT1 gene for osteoporosis in both Chinese and Caucasians," Journal of Bone and Mineral Research, vol. 25, no. 2, pp. 339-355, 2010.

[150] D. L. Koller, I. Alam, Q. Sun, et al., "Genome screen for bone mineral density phenotypes in Fisher 344 and Lewis rat strains," Mammalian Genome, vol. 16, no. 8, pp. 578-586, 2005.

[151] W. G. Beamer, K. L. Shultz, L. R. Donahue, et al., "Quantitative trait loci for femoral and lumbar vertebral bone mineral density in $\mathrm{C} 57 \mathrm{BL} / 6 \mathrm{~J}$ and $\mathrm{C} 3 \mathrm{H} / \mathrm{HeJ}$ inbred strains of mice," Journal of Bone and Mineral Research, vol. 16, no. 7, pp. 11951206, 2001.

[152] R. F. Klein, S. R. Mitchell, T. J. Phillips, J. K. Belknap, and E. S. Orwoll, "Quantitative trait loci affecting peak bone mineral density in mice," Journal of Bone and Mineral Research, vol. 13, no. 11, pp. 1648-1656, 1998.

[153] L. M. Havill, M. C. Mahaney, L. A. Cox, P. A. Morin, G. Joslyn, and J. Rogers, "A quantitative trait locus for normal variation in forearm bone mineral density in pedigreed baboons maps to the ortholog of human chromosome 11q," Journal of Clinical Endocrinology and Metabolism, vol. 90, no. 6, pp. 3638-3645, 2005.

[154] R. F. Klein, J. Allard, Z. Avnur, et al., "Regulation of bone mass in mice by the lipoxygenase gene Alox15," Science, vol. 303, no. 5655, pp. 229-232, 2004.

[155] S. Ichikawa, D. L. Koller, M. L. Johnson, et al., "Human ALOX12, but not ALOX15, is associated with BMD in white men and women," Journal of Bone and Mineral Research, vol. 21, no. 4, pp. 556-564, 2006.

[156] B. H. Mullin, T. D. Spector, C. C. Curtis, et al., "Polymorphisms in ALOX12, but not ALOX15, are significantly associated with BMD in postmenopausal women," Calcified Tissue International, vol. 81, no. 1, pp. 10-17, 2007.

[157] F. Marini and M. L. Brandi, "Pharmacogenetics of osteoporosis: future perspectives," Calcified Tissue International, vol. 84, no. 5, pp. 337-347, 2009.

[158] F. Marini, A. Falchetti, S. Silvestri, et al., "Modulatory effect of farnesyl pyrophosphate synthase (FDPS) rs2297480 polymorphism on the response to long-term aminobisphosphonate treatment in postmenopausal osteoporosis," Current Medical Research and Opinion, vol. 24, no. 9, pp. 2609-2615, 2008. 


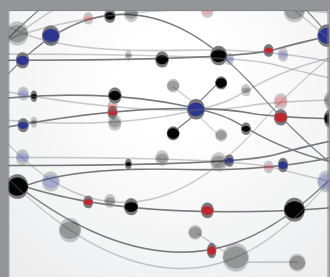

The Scientific World Journal
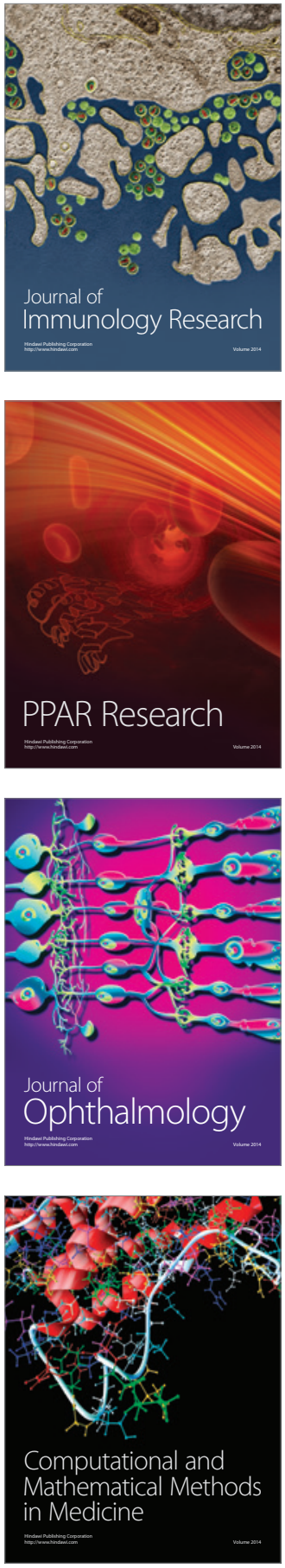

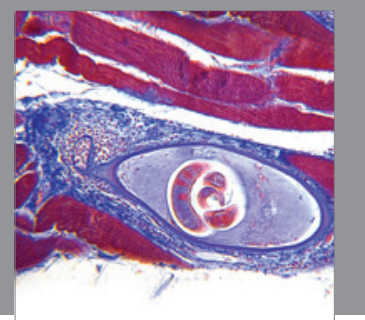

Gastroenterology

Research and Practice
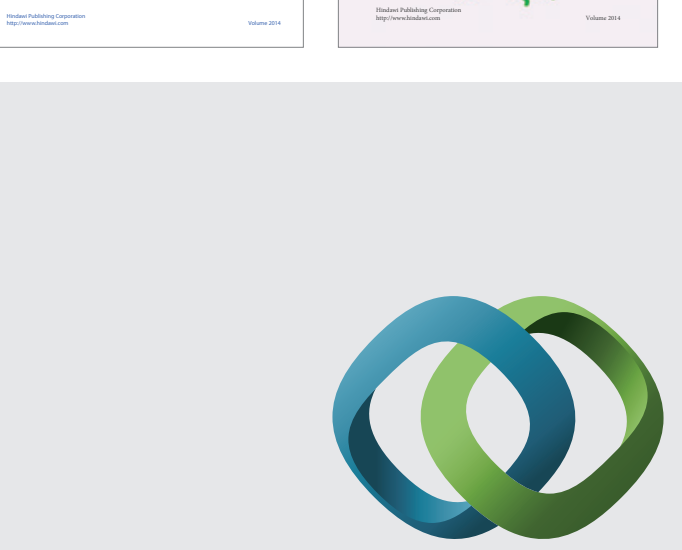

\section{Hindawi}

Submit your manuscripts at

http://www.hindawi.com
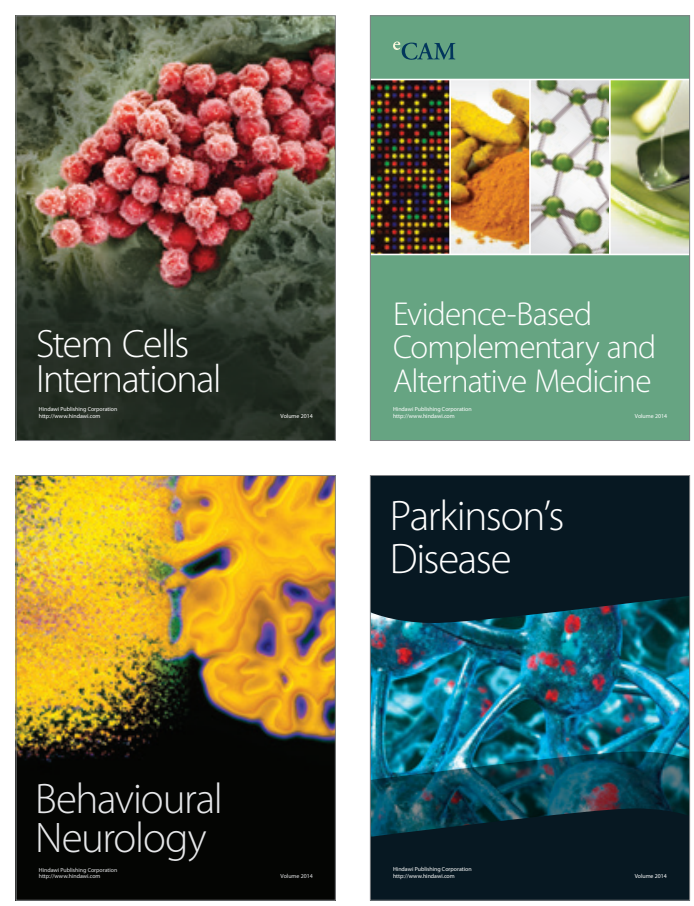

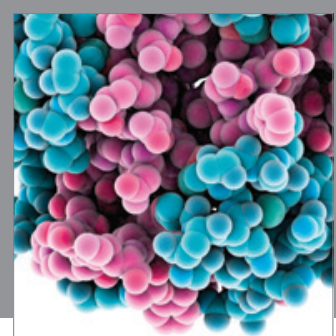

Journal of
Diabetes Research

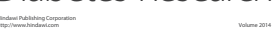

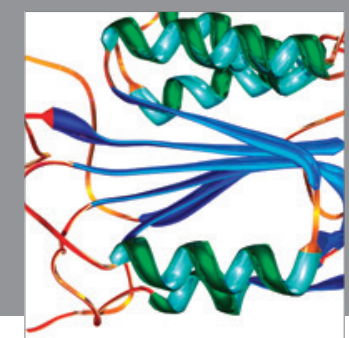

Disease Markers
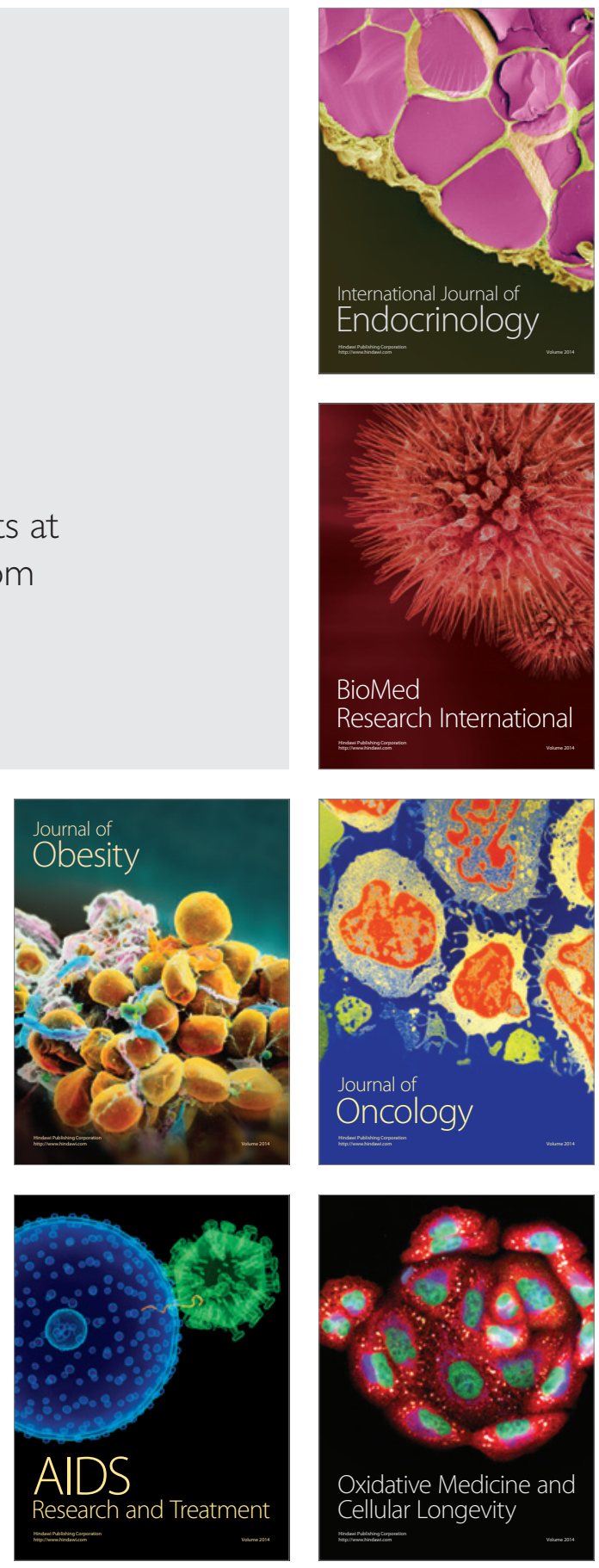